\title{
Aktualisasi Fungsi Keimigrasian dalam Aspek Keamanan sebagai Upaya Integral Penanganan Pandemi Covid-19 Di Indonesia
}

\author{
Herman Suryokumoro \\ Fakultas Hukum Universitas Brawijaya, Malang, Indonesia \\ E-mail: hermans-fh@ub.ac.id
}

\begin{tabular}{l} 
Dikirim: 11/09/2020 \\
\hline Info Artikel \\
Keywords: \\
Immigration; \\
Handling Covid; Law \\
Enforcement. \\
\\
\\
Kata Kunci: \\
Covid; Penegakan \\
Hukum. \\
\end{tabular}

\section{Abstract}

This study aims to analyze the function of immigration in the security aspect, namely as a guard at the entrance to the territory of Indonesia during a pandemic. This function is of course very urgent considering that currently the spread of the Covid 19 virus is getting out of control, one of which is because there are still many foreigners entering Indonesian territory. The research method used is juridical normative, namely analyzing library materials or tracing documents related to the problem under study. The approach used is a statutory approach and a conceptual approach. The results showed that the actualization of the role of the immigration function during a pandemic can be seen from the aspect of immigration regulation and practices carried out by immigration checkpoints (ICP) throughout Indonesia. Meanwhile, the ICP has carried out its function as guardian of state security with the arrival of foreigners and closed several ICPs to limit immigration traffic. There is a significant difference in law enforcement during normal times and during the pandemic, namely the concessions given to foreign nationals in the form of changing overstay fees and deportation cannot be carried out. Deportation cannot be done because in general the person's home country also applies, so temporarily when foreigners who cannot return to their home countries stay in detention centers.

\footnotetext{
Abstrak

Penelitian ini bertujuan untuk menganalisis fungsi keimigrasian dalam aspek keamanan yaitu sebagai "penjaga pintu masuk" ke wilayah negara Indonesia pada saat pandemi. Fungsi ini tentu sangat urgen mengingat saat ini penyebaran virus covid 19 semakin tak terkendali yang salah satunya disebabkan karena masih banyaknya orang asing masuk ke wilayah Indonesia. Metode penelitian yang digunakan adalah yurudis normatif, yaitu menganalisis bahan pustaka atau menelusuri dokumen yang terkait dengan masalah yang diteliti. Pendekatan yang digunakan adalah pendekatan perundang-undangan dan pendekatan konseptual. Hasil penelitian menunjukan bahwa aktualisasi peran fungsi imigrasi
} 


\section{DOI:}

10.47268/sasi.v26i4.400 dalam masa pandemi dapat dilihat dari aspek pengaturan keimigrasian dan praktek yang dilakukan oleh tempat pemeriksaaan imigrasi (TPI) di seluruh wilayah Indonesia. Semenatra itu TPI telah melaksanakan fungsinya sebagai penjaga keamanan negara dengan menolak kedatangan orang asing dan menutup beberapa TPI untuk membatasi lalu lintas keimigrasian. Terdapat perbedaan yang signifikan pada penegakan hukum pada masa normal dan masa pandemi, yaitu kelonggaran yang diberikan kepada warga negara asing dalam bentuk pembebasan biaya overstay dan tidak dapat dilakukan deportasi. Deportasi tidak dapat dilakukan karena pada umumny negara asal orang asing tersebut juga menerapkan pembatasan yang ketat, sehingga untuk sementara waktu banyak orang asing yang tidak dapat pulang ke negera asal terpaksa tinggal di Rudenim.

\section{A. PENDAHULUAN}

Sejak awal tahun 2020, dunia digembarkan dengan adanya virus baru yaitu virus Corona (Covid-19). Virus ini pertama kali ditemukan di Kota Wuhan China yang kemudian menyebar diseluruh belahan dunia yang lain. Virus ini menyebar secara cepat dan tak terkendali hingga pada Januari 2020 WHO mengumumkan dan mencantumkan Covid-19 dalam Public Health Emergency of International Concern (PHEIC) dan meningkatkan status sebagai pandemik pada 11 Maret 2020. ${ }^{1}$

Hinggal 11 September 2020 secara global tercatat jumlah kasus Covid-19 sebanyak 27.738.179, dengan jumlah kematian mencapai 899.916 kasus. Jumlah kasus terbanyak tercatat di Amerika serikat sebanyak 6.272.193 kasus, dengan jumlah kematian sebanyak 188.608 kasus. Sedangkan untuk di Indonesia jumlah kasus per tanggal 11 September 2020 tercatat sebanyak 203.342 kasus dengan jumlah kematian sebanyak 8.336. ${ }^{2}$

Negara-negara di dunia telah melakukan langkah-langkah antisipatif untuk menghentikan penyebaran Covid-19 dinegaranya, salah satunya dengan upaya pembatasan kunjungan ke luar negeri untuk warga negaranya dan membatasi kedatangan WNA di negaranya. Bahkan beberapa negara, seperti Italia, melakukan lockdown dan pembatasan sangat ketat terhadap aktifitas warga negaranya. ${ }^{3}$

Upaya pencegahan penyebaran Covid-19 juga dilakukan oleh pemerintah Indonesia, salah satunya adalah gerakan "Bekerja, Belajar, dan Beribadah dari Rumah". Ada pula tindakan karantina dengan berbagai fasilitas, isolisasi dengan berbagai fasilitas, dan social distancing. Namun, gerakan tersebut dirasa tidak cukup dan kekhawatiran masyarakat tidak menurun. Berbagai gagasan muncul sejalan dengan semakin bertambahnya angka positif corona di Indonesia.

Gagasan adanya lockdown yang mendesak pemerintah untuk menerapkan lockdown beberapa wilayah di Indonesia sebagaimana dilakukan oleh China, Italia, Spanyol, Perancis,

1 World Health Organization. (2020). Coronavirus Disease (Covid 19) Pandemic. Retrieved from https://www.who.int/emergencies/diseases/novel-coronavirus-

2019?gclid=EAIaIQobChMIxdCs9tbf6wIVEbaWCh22qAVIEAAYASAAEgJgl_D_BwE. diakses pada 20 Agustus 2020

2 World Health Organization. (2020). WHO Coronavirus Disease (Covid 19) Dashboard. Retrieved from https://covid19.who.int/table. diakses 11 September 2020

3 Ide, Ella. (2020). Confusion as Italy Prepares to ease Lockdown. Retrieved from https://www.thejakartapost.com/news/2020/05/04/confusion-as-italy-prepares-to-ease-lockdown.html. Diakses 11 Agustus 2020. 
bahkan Malaysia dan Filipina. Namun dengan berbagai macam pertimbangan akhirnya pada 30 Maret Pemerintah RI mengeluarkan Peraturan pemerintah Nomor 23 Tahun 2020 tentang Pembatasan Sosial Berskala Besar dalam Rangka Percepatan Penanganan Corona Virus Desease (Covid-19).

Upaya lain juga dilakukan oleh pemerintah dengan melarang warga negara asing (WNA) masuk maupun transit di wilayah Indonesia. Larangan tersebut tertuang dalam Peraturan Menkumham Nomor 11 Tahun 2020 tentang Pelarangan Sementara Orang Asing Masuk Wilayah Negara Republik Indonesia. Peraturan ini berlaku mulai pada 2 April 2020 sampai waktu yang tak ditentukan.

Adanya larangan masuk bagi WNA ini merupakan langkah tepat yang dapat dilakukan oleh pemerintah RI. Hal ini karena Covid-19 merupakan virus bawaan bukan virus asli. Virus ini dibawa oleh WNA yang datang ke Indonesia, atau WNI yang datang dari luar negeri. ${ }^{4}$ Oleh karenanya pejabat yang berwenang dalam keimigrasian harus menerapkan pembatasan ketat atau bahkan larangan untuk lalu-lintas orang keluar-masuk wilayah Indonesia. ${ }^{5}$

Upaya yang dilakukan imigrasi tersebut merpakan salah satu fungsi imigrasi sebagai penjaga keamanan nasional. ${ }^{6}$ Imigrasi disini berfungsi sebagai penjaga pintu gerbang negara karena imigrasi merupakan institusi pertama dan terakhir yang menyaring kedatangan dan keberangkatan oarang asing ke dan dari wilayah RI. Pelaksanaan fungsi ini ditujukan untuk upaya pencegahan sebagai bagian dari tindakan keimigrasian. Pelaksanaan fungsi keamanan yang ditujukan kepada WNA adalah: ${ }^{7}$

a) Melakukan seleksi terhadap setiap maksud kedatangan orang asing melalui pemeriksaan permohonan visa.

b) Melakukan kerjasama dengan aparatur keamanan negara lain khusus di dalam memeberikan survei perihal penegakkan hukum keimigrasian.

c) Melakukan operasi intelegen keimigrasian bagi kepentingan keamanan negara.

d) Melaksanaan pencegahan dan penangkalan yaitu larangan bagi seseorang untuk meninggalkan wilayah indonesia dalam jangka waktu tertentu dan/atau larangan memasuki wilayah indonesia dalam waktu tertentu.

Pelarangan bagi WNA untuk memasuki wilayah NKRI memang dibenarkan secara hukum. Namun yang harus diperhatikan lebih lanjut adalah bagaimana dengan WNA yang ada berada di Indonesia dalam masa Covid-19, atau jika ada WNA yang sudah terlanjur masuk ke Indonesai selama masa darurat Covid-19, mengingat di Indonesia masih banyak TKA yang ada di Indonesia, khsusunya TKA yang berasal dari China.

Terkait dengan hal tersebut apakah petugas imigrasi dapat melakukan tindakan imigrasi berupa pemulangan ke negara asal atau penangguhan izin tinggal WNA tersebut? Dan selanjutnya bagaimana tanggung jawab negara terkait dengan kebedaan WNA tersebut ditengah wabah Covid-19. Oleh karena perlu dialakukan penelitian tentang aktualisasi peran dan fungsi imigrasi sebagai "penjaga pintu masuk" wilayah NKRI dalam upaya menjaga keamanan dari pandemi Covid-19 dan mengalisis implikasi hukum penegakan hukum oleh imigrasi terhadap WNA yang akan memasuki wilayah NKRI pada saat pandemi Covid-19.

4 Harirah, Zulfa. \& Rizaldi, Annas. (2020). "Merespon Nalar Kebijakan Negara dalam Menangani Pandemi Covid 19 di Indonesia". Jurnal Ekonomi dan Kebijakan Publik Indonesia. 7 (1) 36-53, DOI: https://doi.org/10.24815/ekapi.v7il.17370

5 Santoso, Imam. (2004). Peran Keimigrasian dalam Rangka Peningkatan Ekonomi dan Pemeliharaan Ketahanan Nasional Secara Seimbang, Tesis Hukum Universitas Krisnadwipayana. h. 24

6 Pasal 1 angka 3 Undang Undang Nomor 6 Tahun 2011 tentang Keimigrasian

7 Arif, Moh. (2012). Keimigrasian di Indonesia, Suatu Pengantar. Jakarta: Pusdiklat Departemen Kehakiman. h. 51. 
Karena tidak dapat dipungkiri bahwa meskipun pemerintah telah menerapkan larangan masuk bagi WNA, sejumlah WNA tetap diijinkan masuk dan tinggal di Indonesia.

\section{B. METODE PENELITIAN}

Penelitian ini termasuk dalam penelitian yuridis normatif yang disebut juga dengan penelitian hukum doktrinal. ${ }^{8}$ Penelitian ini adalah penelitian yang dilakukan terhadap kebijakan hukum yang diambil oleh pemerintah dalam hal ini pejabat keimigrasian dalam hal upaya pencegahan penyebaran pandemi Covid-19. Adapun aktualisasi yang dimaksud dalam penelitian ini adalah aktualisasi atau implementasi tugas dan fungsi imigrasi yang tergambar dalam kebijakan hukum pemerintah. Penelitian ini fokus untuk mengkaji hukum (keimigrasian) sebagai pintu masuk WNA ke dalam wilayah NKRI dan tindakan hukum kepada WNA dalam masa tanggap darurat Covid-19.

\section{PEMBAHASAN}

\section{Keimigrasian di Indonesia}

Keimigrasian di Indonesia merupakan bagian dari perwujudan pelaksanaan penegakan kedaulatan atas wilayah Indonesia dalam rangka menjaga ketertiban kehidupan berdasarkan Pancasila dan Undang-undang Dasar Negara Republik Indonesia. Dalam sejarah Indonesia kegiatan keimigrasian terwujud dalam bentuk pemeriksaan keimigrasian yang telah ada sejak zaman penjajahan Belanda. Badan pemerintah kolonial bernama Immigratie Dients merupakan lembaga yang pada saat itu yang bertugas menangani masalah keimigrasian untuk seluruh kawasan Hindia Belanda. ${ }^{9}$ Keimigrasian dari open door policy yang diberlakukan untuk kepentingan pemerintah Kolonial menjadi politik hukum keimigrasian yang bersifat selective policy yang didasarkan pada, kepentingan nasional pemerintah Indonesia. ${ }^{10}$

Undang-undang Republik Indonesia Nomor 9 Tahun 1992 tentang Keimigrasian diberlakukan sebagai dasar hukum pelaksanaan hukum Keimigrasian di Indonesia hingga pada tanggal 5 Mei 2011, ditetapkan Undang-undang Republik Indonesia Nomor 6 Tahun 2011 tentang Keimigrasian sebagai perubahan baru bagi hukum Keimigrasian di Indonesia sebagai penyesuaian dalam pelaksanaan keimigrasian di era globalisasi. Berdasarkan pengertian dalam undang-undang tersebut, keimigrasian adalah hal ihwal lalu lintas orang masuk atau keluar wilayah Indonesia serta pengawasanya dalam rangka menjaga tegaknya kedaulatan negara. ${ }^{11}$ Dari penjelasan UU Keimigrasian, dapat disimpulkan arah kebijakan baru bagi pelaksanaan tugas dan fungsi keimigrasian. Latar belakang lahirnya undangundang ini adalah bergulirnya globalisasi yang mempengaruhi sektor kehidupan masyarakat dan berkembangnya teknologi di bidang informasi dan komunikasi yang melewati batas wilayah kenegaraan, aspek hubungan kemanusiaan yang selama ini bersifat internasional, bersamaan dengan tumbuh dan berkembangnya tuntutan terwujudnya tingkat kesetaraan dalam aspek kehidupan kemanusiaan, mendorong adanya kewajiban untuk menghormati dan menjunjung tinggi hak asasi manusia sebagai bagian kehidupan universal. ${ }^{12}$

8 Waluyo, B. (2002). Penelitian Hukum Dalam Praktek, Jakarta. Sinar Grafika. h. 15

9 Santoso, Imam. Op. Cit, h. 17

10 Dewansyah, Bilal. (2015). Perkembagan Politik Hukum dan Kebutuhan Hukum Keimigrasian Indonesia: Menjawab Sebagian, Melupakan Selebihnya. Hasanudin Law Review, 1 (2), 140-162. DOI: http://dx.doi.org/10.20956/halrev.v1i2.88

11 Arif, Moh. Opcit. h. 16-17

12 Syahrin, M.A. (2018). Menakar Kedaulatan Negara dalam Perspektif Keimigrasian. Jurnal Penelitian 
UU keimigrasian memiliki penekanan pada berbagai aspek, yaitu diantaranya Hak Asasi Manusia (HAM) dan Transnational Organized Crime. Dalam bidang HAM misalnya, setiap warga negara Indonesia (WNI) memiliki hak yang sama untuk masuk dan keluar wilayah Indonesia, dan tidak berlakunya penangkalan bagi WNI. Dalam bidang Transnational Organized Crime, keimigrasian memiliki peranan penting dalam mencegah tindak pidana transnasional seperti perdagangan orang, penyelundupan manusia, dan tindak pidana narkotika yang banyak dilakukan oleh sindikat internasional. Dalam UU keimigrasian yang sebelumnya bersifat selective policy (kebijakan saringan) berubah menjadi selective policy yang menjunjung tinggi HAM. ${ }^{13}$

Untuk menjalankan UU Keimigrasian, maka pemerintah mengeluarkan Peraturan Pemerintah Nomor 31 Tahun 2013 tentang Peraturan Pelaksanaan Undang-undang Nomor 6 Tahun 2011 tentang Keimigrasian (PP No. 31 Tahun 2013) yang mana pelaksanaannya masih tergantung pada peraturan sebelumnya selama tidak bertentangan dengan undang-undang dan peraturan pemerintah di bidang Keimigrasian.

Dari beberapa penjelasan tersebut, maka yang menjadi objek dari keimigrasian meliputi dua hal yaitu: ${ }^{14}$

1) Lalu lintas orang;

2) Pengawasan keimigrasian.

Sedangkan untuk subyek dari keimigrasian meliputi dua hal juga yaitu: ${ }^{15}$

1) Orang yang masuk;

2) Keluar wilayah Negara republik Indonesia dan orang asing yang berada di wilayah Negara Republik Indonesia.

Selain itu, fungsi Imigrasi dalam kegiatannya mengandung 4 fungsi utama yaitu sebagai berikut: ${ }^{16}$

1) Fungsi Pelayanan Masyarakat

Imigrasi dituntut untuk memberi pelayanan prima di bidang keimigrasian baik kepada WNI/WNA. Pelayanan bagi WNA terdiri dari:

a) Pemberian Dokumen Keimigrasian (DOKIM) berupa Kartu Izin Tinggal Terbatas, Kartu Izin tinggal tetap, kemudahan khusus keimigrasian

b) Perpanjangan izin tinggal meliputi: Visa kunjungan wisata, visa kunjungan sosial budaya, visa kunjungan usaha.

c) Perpanjangan DOKIM meliputi KITAS, KITAP, DAHSUSKIM

d) Pemberian izin masuk kembali, izin bertolak, dan

e) Pemberian tanda bertolak dan masuk

2) Fungsi Penegakan Hukum

Penegakkan hukum terhadap WNA ditujukan pada permasalahan:

a) Pemalsuan identitas WNA

b) Pendaftaran orang asing dan pemberian buku pengawasan orang asing

c) Penyalahgunaan izin tinggal

d) Masuk secara ilegal/berada secara ilegal

Hukum De Jure, 18 (1) 43-57. DOI: http://dx.doi.org/10.30641/dejure.2018.V18.43-57

13 Sande, J.P. (2020). Selective Policy Imigrasi Indonesia terhadap Orang Asing dari Negara Calling Visa. Indonesian Perspective, 5 (1). DOI: https://doi.org/10.14710/ip.v5i1.30196

14 Sihombing, Sihar. (2013). Hukum Keimigrasian dalam Hukum Indonesia, Jakarta: Nuansa Aulia. h. 3

15 Ibid,

16 Wijayanti, Herlin. (2011). Hukum Kewarganegaraan dan Keimigrasian, Malang: Bayumedia Publishing. h. 132-134 
e) Pemantauan razia

f) Kerawanan keimigrasian secara geografis dalam pelintasan.

3) Fungsi Keamanan

Imigrasi disini berfungsi sebagai penjaga pintu gerbang negara karena imigrasi merupakan institusi pertama dan terakhir yang menyaring kedatangan dan keberangkatan oarang asing ke dan dari wilayah RI. Pelaksanaan fungsi ini ditujukan untuk upaya pencegahan sebagai bagian dari tindakan keimigrasian.Pelaksanaan fungsi keamanan yang ditujukan kepada WNA adalah:

a) Melakukan seleksi terhadap setiap maksud kedatangan orang asing melalui pemeriksaan permohonan visa

b) Melakukan kerjasama dengan aparatur keamanan negara lain khusus di dalam memeberikan survei perihal penegakkan hukum keimigrasian.

c) Melakukan operasi intelegen keimigrasian bagi kepentingan keamanan negara.

d) Melaksanaan pencegahan dan penangkalan yaitu larangan bagi seseorang untuk meninggalkan wilayah indonesia dalam jangka waktu tertentu dan/atau larangan memasuki wilayah indonesia dalam waktu tertentu.

4) Fungsi Fasilitator

Fungsi ini terfokus pada pembangunan ekonomi dan kesejahteraan masyarakat Indonesia. Hal ini berhubungan dengan perizinan orang asing yang akan berinvestasi (Penanam Modal Asing) di Indonesia dengan tujuan kesejahteraan masyarakat Indonesia terutama pemabangunan ekonomi Indonesia agar lebih dipermudah.

\section{Aktualisasi Peran dan Fungsi Imigrasi Sebagai "Penjaga Pintu Masuk" Wilayah NKRI dalam Upaya Menjaga Keamanan dari Pandemi Covid-19}

Merujuk pada penjelasan sebelumnya bahwa terdapat 4 fungsi imigrasi yaitu fungsi pelayanan masyarakat, fungsi penegakan hukum, fungsi keamanan, dan fungsi fasilitator. Terkait dengan adanya pandemi Covid 19 fungsi keamanan imigrasi yang menjadi perhatian utama. Imigrasi disini berfungsi sebagai penjaga pintu gerbang negara karena imigrasi merupakan institusi pertama dan terakhir yang menyaring kedatangan dan keberangkatan oarang asing ke dan dari wilayah RI. Pelaksanaan fungsi ini ditujukan untuk upaya pencegahan sebagai bagian dari tindakan keimigrasian.

Aktualisasi fungsi ini dapat dilihat dari adanya restriksi atau pembatasan bagi WNA untuk datang ke Indonesia sebagaimana diatur dalam Permenkumham 11/2020. Pembatasan lalu lintas orang melalui pintu-pintu pemeriksaan Imigrasi dilaksanakan berdasarkan Permenkumham 11/2020 yang berlaku sejak tanggal 2 April 2020 pukul 00.00 WIB hingga batas waktu yang belum ditentukan.

Namun demikian, aturan larangan masuk dan transit ini memiliki pengecualian terhadap sejumlah WNA. Mereka antara lain yang memiliki kartu izin tinggal terbatas (KITAS), kartu izin tinggal tetap (KITAP), pemegang izin tinggal diplomatik dan izin tinggal dinas. Selain itu, tenaga bantuan dan dukungan medis dan pangan; awak alat angkut baik laut, udara maupun darat; serta orang asing yang bekerja pada proyek-proyek Strategis Nasional juga diperbolehkan dengan syarat tertentu antara lain memiliki surat keterangan sehat dalam bahasa Inggris yang dikeluarkan oleh otoritas kesehatan dari masing-masing negara dan telah berada 14 hari di wilayah atau negara yang bebas Covid-19.

Permenkumham tersebut juga mengatur regulasi bagi orang asing yang berada di Indonesia. Pertama, orang asing pemegang Izin Tinggal Kunjungan (termasuk bebas visa kunjungan dan Visa on Arrival) yang telah berakhir atau tidak dapat diperpanjang izin tinggalnya, akan diberikan izin tinggal keadaan terpaksa secara otomatis tanpa perlu 
mengajukan permohonan ke Kantor Imigrasi serta tak dipungut biaya. Kemudian, orang asing pemegang Izin Tinggal Terbatas dan Izin Tinggal Tetap yang telah berakhir atau tidak dapat diperpanjang lagi, akan diberikan penangguhan dan diberikan izin tinggal keadaan terpaksa secara otomatis tanpa perlu mengajukan permohonan ke Kantor Imigrasi serta tidak dipungut biaya. ${ }^{17}$

Permenkumham 11/2020 tersebut dapat dikatakan sebagai kebijakan keimigrasian dalam masa darurat Covid, dimana terjadi pergeseran fungsi imigrasi normatif sebagai penjaga kedaulatan beralih kepada fungsi kemanfaatan ${ }^{18}$ yaitu dengan adanya kebijakan selektif keimigrasian ${ }^{19}$. Selektif dalam hal ini dimaknai dalam pembatasan.

Kebijakan selektif ini merupakan pelaskanaan tanggung jawab negara terhadap warga negara maupun orang asing yang tinggal di wilayah negaranya dalam masa pandemi. ${ }^{20}$ Negara bertanggung jawab atas keselamatan warga negara dari gangguan pihak luar, dalam hal ini virus menular. Disamping juga berkewajiban menjaga hak-hak orang asing yang berada di wilayah NKRI.

Setiap Orang Asing yang masuk ke wilayah Indonesia tidak terlepas dari hak dan kewajiban hukum yang melekat kepadanya sebagaimana tercantum dalam Deklarasi Universal Hak Asasi Manusia (DUHAM). ${ }^{21}$ Tidak semua hak yang terdapat dalam DUHAM harus dipenuhi terhadap Orang Asing yang berada di suatu yurisdiksi negara, salah satunya adalah hak untuk berpartisipasi dalam pemerintahan, sehingga hanya hak-hak tertentu yang harus dihormati, dipenuhi, dan dilindungi oleh Negara tujuan dari orang asing tersebut.

Meskipun dilakukan pembatasan secara ketat terhadap orang asing yang akan memesuki wilayah Indonesia, namun kebijakan keimigrasian dalam masa pandemi juga tidak lepas dari adanya tanggung jawab negara untuk melindungi hak orang asing yang berada di wilayah Indonesia pada masa pandemi. Tanggung jawab tersebut teraktualisasi dalam Surat Edaran Nomor: IMI-GR.01.01-1102 Tahun 2020 Tentang Layanan Izin Tinggal Keimigrasian Dalam Tatanan Kenormalan Baru, yang pada dasarnya adalah memberikan kemudahan bagi orang asing untuk memperoleh ijin tinggal selama orang asing tersebut tidak dapat kembali ke negara asalnya akibat pembatasan.

Aktualisasi peran dan fungsi imigrasi dalam masa pandemi tidak hanya dilihat dari aspek pengaturan keimigrasian dalam masa darurat tetapi juga praktek yang dilakukan oleh tempat pemeriksaaan imigrasi di seluruh wilayah Indonesia. Terdapat 182 Tempat Pemeriksaan Imigrasi (TPI) di Indonesia yang menjadi "pintu keluar-masuk" wilayah kedaulatan Indonesia yang terdiri dari: 37 Bandar Udara, 90 TPI Pelabuhan Laut, 11 TPI Pos Lintas Batas Internasional, dan 44 TPI Pos Lintas Batas Tradisional. ${ }^{22}$ Dari TPI tersebut, imigrasi Indonesia telah melakukan penolakan terhadap 242 orang asing yang akan memasuki wilayah Indonesia. ${ }^{23}$ Selain itu, sebagai langkah preventif, pemerintah juga telah menutup sementara beberapa TPI atau Pos Lintas Batas Negara untuk mencegah penyebaran

17 Permenkumham Nomor 11 Tahun 2020

18 Syahrin, M.A. (2020). Penegakan Hukum Keimigrasian Indonesia dalam Keadaan Darurat (Covid 19). Research Gate. DOI: 10.13140/RG.2.2.17315.48160/1

19 Penjelasan Umum Undang Undang Nomor 6 Tahun 2011 tentang Keimigrasian.

20 Fahroy, C.A. (2017). Aspek Hukum Internasional pada Batas "Imajiner" Negara, Wawasan Yuridika, 1(1) 54-63. DOI: http://dx.doi.org/10.25072/jwy.v1i1.127

21 Muhlisa, A.N. \& Roisah, Kholis. (2020). Penegakan Hukum Keimigrasian terhadap Penyalahgunaan Visa Izin Tinggal Kunjungan Lewat Batas awaktu (Overstay) Pada Warga Negara Asing. Jurnal Pembangunan Hukum Indonesia, 2 (2), pp. 145-157. DOI. https://doi.org/10.14710/jphi.v2i2.145-147

22 Keputusan Menteri Hukum dan HAM Nomor M.HH-2.GR.02.02 Tahun 2020 tentang Tempat Pemeriksaan Imigrasi.

23 Direktorat Lalu Lintas Keimigrasian, April 2020 
Covid 19.

Tabel 1. Daftar Tempat Pemeriksaan Imigrasi yang Ditutup Saat Pandemi

\begin{tabular}{|c|c|c|}
\hline No & Tempat Pemeriksaan Imigrasi & Keterangan \\
\hline 1 & $\begin{array}{l}\text { Pos Lintas Batas Internasional } \\
\text { Skow }\end{array}$ & $\begin{array}{l}\text { Telah ditutup sejak tanggal } 31 \text { Jan } 2020 \text { atas } \\
\text { permintaan Negara PNG }\end{array}$ \\
\hline 2 & $\begin{array}{l}\text { Pos Lintas Batas Internasional } \\
\text { Miangas }\end{array}$ & $\begin{array}{l}\text { Telah ditutup sejak bulan } \\
\text { permintaan Negara Filipina }\end{array}$ \\
\hline 3 & $\begin{array}{l}\text { Pos Lintas Batas Internasional } \\
\text { Marore }\end{array}$ & $\begin{array}{l}\text { Telah ditutup sejak bulan Feb } 2020 \text { atas } \\
\text { permintaan Negara Filipina }\end{array}$ \\
\hline 4 & $\begin{array}{l}\text { Pos Lintas Batas Internasional } \\
\text { Nunukan }\end{array}$ & $\begin{array}{l}\text { Telah ditutup sejak bulan } 18 \text { Maret } 2020 \text { atas } \\
\text { permintaan Negara Malaysia }\end{array}$ \\
\hline 5 & $\begin{array}{l}\text { Pelabuhan Laut Bandar Sri } \\
\text { Setia Raja }\end{array}$ & $\begin{array}{l}\text { Telah ditutup sejak tanggal } 21 \text { Maret } 2020 \\
\text { berdasarkan surat Kepala Dinas Perhubungan } \\
\text { Kabupaten Bengkalis tanggal } 20 \text { Maret } 2020 \text { hal } \\
\text { Pemberitahuan Penutupan Pelabuhan Bandar Sri } \\
\text { Setia Raja Selatbaru Kec. Bantan }\end{array}$ \\
\hline 6 & Pelabuhan Laut Dumai & $\begin{array}{l}\text { Telah ditutup sejak tanggal } 21 \text { Maret } 2020 \\
\text { berdasarkan surat Kepala Dinas Perhubungan } \\
\text { Kota Dumai Nomor 500 DISHUB } 225 \text { tanggal } 20 \\
\text { Maret } 2020 \text { perihal Pemberitahuan penutupan } \\
\text { Pelabuhan }\end{array}$ \\
\hline 7 & $\begin{array}{l}\text { Pelabuhan Laut Sri Bintan } \\
\text { Pura }\end{array}$ & Telah ditutup sejak tanggal 23 Maret 2020 \\
\hline 8 & $\begin{array}{l}\text { Pelabuhan Laut Bandar Seri } \\
\text { Udana Lobam }\end{array}$ & Telah ditutup sejak tanggal 12 Maret 2020 \\
\hline 9 & Pelabuhan Laut Teluk Nibung & $\begin{array}{l}\text { Telah ditutup sejak tanggal } 19 \text { Maret } 2020 \text { s.d } 31 \\
\text { Maret } 2020\end{array}$ \\
\hline 10 & $\begin{array}{l}\text { Pelabuhan Laut Tanjung } \\
\text { Harapan }\end{array}$ & $\begin{array}{l}\text { Telah ditutup sejak tanggal } 27 \text { Maret } 2020 \\
\text { berdasarkan Surat Edaran Kepala Kantor } \\
\text { Kesyahbandaran dan Otoritas Pelabuhan } \\
\text { Selatpanjang tanggal } 27 \text { Maret } 2020 \text { tentang } \\
\text { Ketentuan Keberangkatan Kedatangan Kapal } \\
\text { Penumpang dan Barang dan ke Luar Negeri } \\
\text { Terhadap Upaya Pencegahan dan Penyebaran } \\
\text { Virus Corona (COVID-19) di Lingkungan } \\
\text { Wilayah Kerja Pelabuhan Selatpanjang }\end{array}$ \\
\hline 11 & PLB di Provinsi NTT & $\begin{array}{l}\text { Berdasarkan surat dari Republica Democratica De } \\
\text { Timor Leste No AU } 05 \text { 2020PLB tanggal } 03 \text { April } \\
2020 \text { yang menyatakan bahwa pihak NTT hanya } \\
\text { membuka exit entry point pada hari Rabu pukul }\end{array}$ \\
\hline
\end{tabular}


12 PLB di Provinsi Kalimantan Barat

\begin{abstract}
Telah ditutup sejak tanggal 24 April 2020 berdasarkan surat Gubernur Kalimantan Barat tanggal 24 April 2020 tentang Penutupan PLBN bagi masuknya WNI dari Sarawak Malaysia kecuali bagi warga Kalimantan Barat. Namun berdasarkan ketentuan Pasal 14 ayat 1 UU Nomor 6 Tahun 2011 bahwa setiap WNI tidak dapat ditolak masuk wilayah Indonesia sehingga pintu exit entry point RI-Malaysia hanya dibka untuk (1) WNI yang datang dari Malaysia dan (2) WNI Malaysia yang akan kembali ke negaranya.
\end{abstract}

Sumber: Direktorat lalu Lintas Keimigrasian, 2020

Kebijakan pemerintah untuk membatasi keluar masuk warga negara merupakan pergeseran fungsi imigrasi pada masa pandemi. Fungsi pada awalnya adalah sebagai "penjaga pintu masuk" yang bertujuan memperlancar lalu lintas orang, namun dalam masa pandemi ini fungsi keimigrasian lebih apda penjaga keamanan negara dengan menerapkan larangan, yang awalnya boleh menjadi tidak boleh, yang awalnya diizinkan menjadi tidak diizinkan. Dengan demikian, pada masa masa pandemi ini aktualisasi peran imigrasi tidak hanya menekankan pada aspek normatif namun pada aspek kemanfaatan, yaitu menjaga keselamatan seluruh warga negara Indonesia dari penyebaran Covid 19.

\section{Implikasi Hukum Penegakan Hukum oleh Imigrasi terhadap WNA yang Memasuki Wilayah NKRI pada Masa Pandemi Covid-19}

Fungsi penegakan hukum dalam imigrasi merupakan tindakan hukum yang dilakukan oleh keimigrasian terkait dengan adanya pelanggaran dalam ketentuan keimigrasian. Penegakan hukum imigrasi dapat dilihat dari dua aspek yaitu penegakan hukum preventif dan penegakan hukum represif. ${ }^{24}$ Penegakan hukum preventif dilakukan oleh intelijen keimigrasian yang melakukan pengawasan agar tidak terjadi pelanggaran. Sementara itu penegakan hukum repesif dilakukan dengan menerapkan tindakan administratif keimigrasian dan penyidikan keimigrasian, misalnya dalam hal warga negara asing yang over stay.

Pelaksanaan penegakan hukum keimigrasian pada masa darurat Covid 19 mengalami perubahan menyesuaikan dengan tatanan kenormalan baru. Pertama dalam aspek pengawasan, pengawasan dilaksanakan secara terbatas mengikuti perubahan jam kerja pegawai imigrasi. Pengawasan pada perusahaan, tempat tinggal dan lainnya mulai dibatasi, pengawasan menunggu adanya laporan dari masyarakat. Dalam masa pandemi trend pelanggaran terhadap imigrasi berkurang seiring dengan terbatasnya ruang gerak keluarmasuk wilayah Indonesia.

Kedua dalam aspek tindakan administratif keimigrasian, terjadi kelonggaran terhadap

${ }^{24}$ Syahrin, M.A. (2019). Polarisasi Penegakan Hukum Keimigrasian Kontemporer: Aksiologi NormatifEmpiris. Majalah Hukum Nasional, 49 (1) pp. 59-89. DOI: https://doi.org/10.33331/mhn.v49i1.93 
beberapa tindakan pelanggaran, diantaranya yaitu warga negara asing tidak kenakan biaya overstay dan penundaan terhadap deportasi, hal ini berdasarkan ketentuan SE Dirjen Pencegahan dan Pengendalian Penyakit No. SR.04.03/II/6689/2020 tentang Pelaksanaan Angkutan Udara dalam Rangka Pencegahan Penyebaran Covid-19 untuk menunda sementara dari dan ke Indonesia melalui pesawat udara. Dengan demikian praktis warga negara asing tidak dapat pulang kenegara asalnya pada saat darurat Covid 19. Ketiga dalam aspek penyidikan keimigrasian, hingga saat ini belum ada aturan atau SOP yang mengatur secara khusus penyidikan keimigrasian pada masa pandemi. Akibatnya bagi warga negara asing yang telah diputus bersalah tidak dapat dideportasi.

Masalah lain dalam pengakan hukum keimigrasain pada masa pandemi adalah terkait dengan rumah detensi imigrasi. Belum ada SOP yang memadai tentang pelaksanaan penegakan dan perlindungan hukum di dalam Rudenim. Selama ini pelaksanaan Rudemin mengikuti protokol kesehatan pada umumnya seperti penyemprotan disinfektan, hand sanitizer dan rapid tes untuk deteni. Namun demikian hal ini tidak dapat dilakukan terus menerus mengingat keterbatasan anggaran untuk Rudenim. Disamping itu, Rudenim tidak hanya menangani WNA yang bermasalah tetapi juga imigran dan pengungsi yang tidak dapak dapat kembali ke negara asalnya, sehingga penghuni Rudemin semakin banyak sementara pola pengelolaan Ridemin masih konvensional.

\section{P E N U T U P}

Aktualisasi peran dan fungsi imigrasi dalam masa pandemi dapat dilihat dari aspek pengaturan keimigrasian dan praktek yang dilakukan oleh tempat pemeriksaaan imigrasi di seluruh wilayah Indonesia. Aktualisasi fungsi pengamanan dapat dilihat dari adanya restriksi atau pembatasan bagi WNA untuk datang ke Indonesia sebagaimana diatur dalam Permenkumham 11/2020. Semenatra itu TPI telah melaksanakan fungsinya sebagai penjaga keamanan negara dengan menolak kedatangan orang asing dan menutup beberap TPI untuk membatasi lalu lintas keimigrasian.

Penegakan hukum keimigrasian apda masa darurat Covid tetap dilakukan dengan menyesuaikan dengan tata kenormalan baru. Terdapat perbedaan yang signifikan pada penegakan hukum pada masa normal dan masa pandemi, yaitu kelonggaran yang diberikan kepada warga negara asing dalam bentuk pembebasan biaya overstay dan deportasi. Warga negara asing yang tidak dapat diportasi akibat negara asalnya sedang mengalami lockdown ditempatkan pada Rudemin yang ada. Namun demikian hal ini masih menjadi masalah karena belum ada SOP Rudemin pada masa covid dan keterbatasan anggaran yang ada.

\section{DAFTAR PUSTAKA}

\section{Jurnal}

[1] Dewansyah, Bilal. (2015). Perkembagan Politik Hukum dan Kebutuhan Hukum Keimigrasian Indonesia: Menjawab Sebagian, Melupakan Selebihnya. Hasanudin Law Review, 1 (2), 140-162. DOI: http://dx.doi.org/10.20956/halrev.v1i2.88

[2] Fahroy, C.A. (2017). Aspek Hukum Internasional pada Batas "Imajiner" Negara, Wawasan Yuridika, 1(1) 54-63. DOI: http://dx.doi.org/10.25072/jwy.v1i1.127

[3] Harirah, Zulfa. \& Rizaldi, Annas. (2020). Merespon Nalar Kebijakan Negara dalam Menangani Pandemi Covid 19 di Indonesia. Jurnal Ekonomi dan Kebijakan Publik Indonesia. 7 (1) 36-53, DOI: https://doi.org/10.24815/ekapi.v7i1.17370

[4] Muhlisa, A.N. \& Roisah, Kholis. (2020). Penegakan Hukum Keimigrasian terhadap 
Penyalahgunaan Visa Izin Tinggal Kunjungan Lewat Batas awaktu (Overstay) Pada Warga Negara Asing. Jurnal Pembangunan Hukum Indonesia, 2 (2), pp. 145-157. DOI. https://doi.org/10.14710/jphi.v2i2.145-147

[5] Sande, J.P. (2020). Selective Policy Imigrasi Indonesia terhadap Orang Asing dari Negara Calling Visa. Indonesian Perspective, 55 (1). DOI: https://doi.org/10.14710/ip.v5i1.30196

[6] Syahrin, M.A. (2018). Menakar Kedaulatan Negara dalam Perspektif Keimigrasian. Jurnal Penelitian Hukum De Jure, 18 (1) 43-57. DOI: http://dx.doi.org/10.30641/dejure.2018.V18.43-57

[7] Syahrin, M.A. (2019). Polarisasi Penegakan Hukum Keimigrasian Kontemporer: Aksiologi Normatif-Empiris. Majalah Hukum Nasional, 49 (1) pp. 59-89. DOI: https://doi.org/10.33331/mhn.v49i1.93

[8] Syahrin, M.A. (2020). Penegakan Hukum Keimigrasian Indonesia dalam Keadaan Darurat (Covid 19). Research Gate. DOI: 10.13140/RG.2.2.17315.48160/1

\section{Buku}

[9] Arif, Moh. (2012). Keimigrasian di Indonesia, Suatu Pengantar. Jakarta: Pusdiklat Departemen Kehakiman.

[10] Sihombing, Sihar. (2013). Hukum Keimigrasian dalam Hukum Indonesia Jakarta: Nuansa Aulia

[11]Waluyo, B. (2002). Penelitian Hukum Dalam Praktek, Jakarta. Sinar Grafika.

[12] Wijayanti, Herlin. (2011). Hukum Kewarganegaraan dan Keimigrasian, Malang: Bayumedia Publishing

\section{Tesis}

[13] Santoso, Imam. (2004). Peran Keimigrasian dalam Rangka Peningkatan Ekonomi dan Pemeliharaan Ketahanan Nasional Secara Seimbang, Tesis Hukum Universitas Krisnadwipayana.

\section{Online/World Wide Web}

[14] World Health Organization. (2020). Coronavirus Disease (Covid 19) Pandemic. Retrieved from https://www.who.int/emergencies/diseases/novel-coronavirus2019?gclid=EAIaIQobChMIxdCs9tbf6wIVEbaWCh22qAVIEAAYASAAEgJg1_D_B wE.

[15] World Health Organization. (2020). WHO Coronavirus Disease (Covid 19) Dashboard. Retrieved from https://covid19.who.int/table.

[16]Ide, Ella. (2020). Confusion as Italy Prepares to ease Lockdown. Retrieved from https://www.thejakartapost.com/news/2020/05/04/confusion-as-italy-prepares-to-easelockdown.html. 